\title{
PENERAPAN AJAX DAN WEB SERVICE PADA SISTEM TUTORIAL PEMROGRAMAN WEB.
}

\section{IMPLEMENTATION OF AJAX AND WEB SERVICE FOR WEB PROGRAMMING TUTORIAL}

\author{
Ikrimach \\ Jurusan Teknik Informatika, Fakultas Teknologi Informasi dan Elektro, Universitas Teknologi Yogyakarta \\ e-mail: Ikrimach@staff.uty.ac.id
}

\begin{abstract}
The progress of information technology that is increasingly widespread and the demand for data requirements needed by users causes information to be presented quickly and objectively to meet those needs. The problem faced in presenting material in the form of current programming scripts is a static information presentation system, this makes the learning process less efficient. To get good performance in the learning process, a tutorial system is needed that is able to execute programming scripts interactively. To execute commands properly, small data traffic is needed so that the server can work more freely and can respond to requests faster. This tutorial system was developed with the AJaX programming language and web service method to get better processing performance. The web programming tutorial system developed provides examples of scripts or web programming codes that are equipped with descriptions or explanations. In addition, this system also has the ability to execute examples of programs that are presented to get the output results. The results of the study show that the use of web programming tutorials as a model of educational support systems is faster, effective and practical because it can be used by anyone, anywhere and anytime.
\end{abstract}

Keywords - Web Service, Web Programming, AJaX

\section{Pendahuluan}

Pesatnya perkembangan ilmu pengetahuan dan teknologi pada saat ini memberikan banyak kemudahan dalam penyampaian informasi. Kemajuan teknologi informasi yang semakin luas serta tuntutan akan pengolahan data yang semakin meningkat menyebabkan informasi harus disajikan dengan cepat dan objektif. Masalah yang dihadapi pada penyajian bahan atau materi yang berupa script pemrograman, saat ini masih banyak disajikan dalam bentuk buku dan modul-modul, hal ini membuat waktu belajar akan lebih lama dan kurang efisien. Untuk mendapatkan performa yang baik diperlukan sebuah sistem yang mampu mengeksekusi perintah dengan baik. Pengambilan dan menampilkan data dengan lebih cepat dapat terjadi dengan karena ukuran data yang kecil. Ukuran data yang lebih kecil berdampak pada traffic data yang lebih kecil pada jaringan dan pemrosesan yang dilakukan pada sisi klien sehingga membuat server dapat bekerja dengan lebih leluasa dan dapat merespon request yang lebih banyak. Solusi dari masalah tersebut adalah dengan adanya sebuah sistem tutorial yang mampu menyajikan materi script pemrograman serta mampu untuk mengeksekusi script tersebut secara interaktif. Penelitian ini bertujuan untuk menerapkan teknologi ajax dan web service pada sistem tutorial pemrograman web. Teknologi ajax dan web service telah banyak diterapkan diberbagai bidang seperti pembangunan sistem administrasi untuk data penduduk [1], pembangunan sistem pariwisata [2], pembangunan sistem informasi bencana alam [3], sistem 
pemantau kepuasan layanan akademik [4], pembangunan sistem rumah pintar [5], dan pembangunan sistem pembelajaran adaptif [6]. Secara umum, penerapan web service sangat berguna untuk mempercepat pemrosesan data pada sebuah sistem [1], dan mendukung sistem navigasi dan kontent yang adaptif karena mampu menyesuaikan dengan kebutuhan pelajar [6]. Untuk itu penelitian ini diharapkan dapat membantu pihak-pihak yang terkait dalam pembelajaran pemrograman web dasar, yang sebelumnya masih banyak disajikan dalam bentuk modul manual, sehingga proses pembelajaran akan lebih efisien dan praktis. Lebih jauh lagi dengan adanya system tutorial yang dinamis ini diharapkan bisa membantu dalam proses pembelajaran yang lebih efisien dan praktis, karena dapat digunakan oleh siapa saja, dimana saja dan kapan saja.

\section{Landasan Teori}

Bagian ini menjabarkan beberapa landasan teori yang berkaitan dengan teknologi ajax dan web service, serta penjelasan mengenai sistem tutorial.

\subsection{AJaX}

Asynchronous JavaScript and XMLHTTP (AJaX) adalah suatu teknik pemrograman berbasis web untuk menciptakan aplikasi web interaktif. Tujuannya adalah untuk memindahkan sebagian besar interaksi pada komputer web server, melakukan pertukaran data dengan server di belakang layar, sehingga halaman web tidak harus dibaca ulang secara keseluruhan setiap kali seorang pengguna melakukan perubahan. Hal ini akan meningkatkan interaktivitas, kecepatan, dan usability. Ajax merupakan kombinasi dari beberapa teknologi termasuk Data Object Model (DOM) untuk menyajikan informasi secara dinamis, XMLHttpRequest untuk melakukan pertukaran data dengan web server, XML dan JSON yang digunakan sebagai jenis dokumen transfer [7].

\subsection{Web Service}

Web service adalah sebuah sistem perangkat lunak yang didesain untuk mendukung mesin interoperabilitas ke mesin interaksi melalui jaringan. Web Service Description Language (WSDL) adalam bahasa definisi antarmuka berbasis XML yang menyediakan fungsionalitas pada web service. Arsitektur web service tidak menetapkan bagaimana web service diimplementasikan, dan tidak membatasi bagaimana web service mungkin digabungkan. Arsitektur web service merupakan arsitektur interoperabilitas yang mengidentifikasi unsur-unsur global. Sebuah web service adalah suatu gagasan abstrak yang dilaksanakan oleh agen concrete. Sebuah agen dapat berupa potongan perangkat lunak atau perangkat keras yang akan mengirim dan menerima pesan. Gambar 1 menunjukkan mekanisme pertukaran pesan yang didokumentasikan dalam Web Service on Device (WSD). WSD adalah mesin yang mendefinisikan format pesan, datatypes, transportasi protokol, dan transportasi serialisasi format yang harus digunakan oleh penyedia agen [7]. 


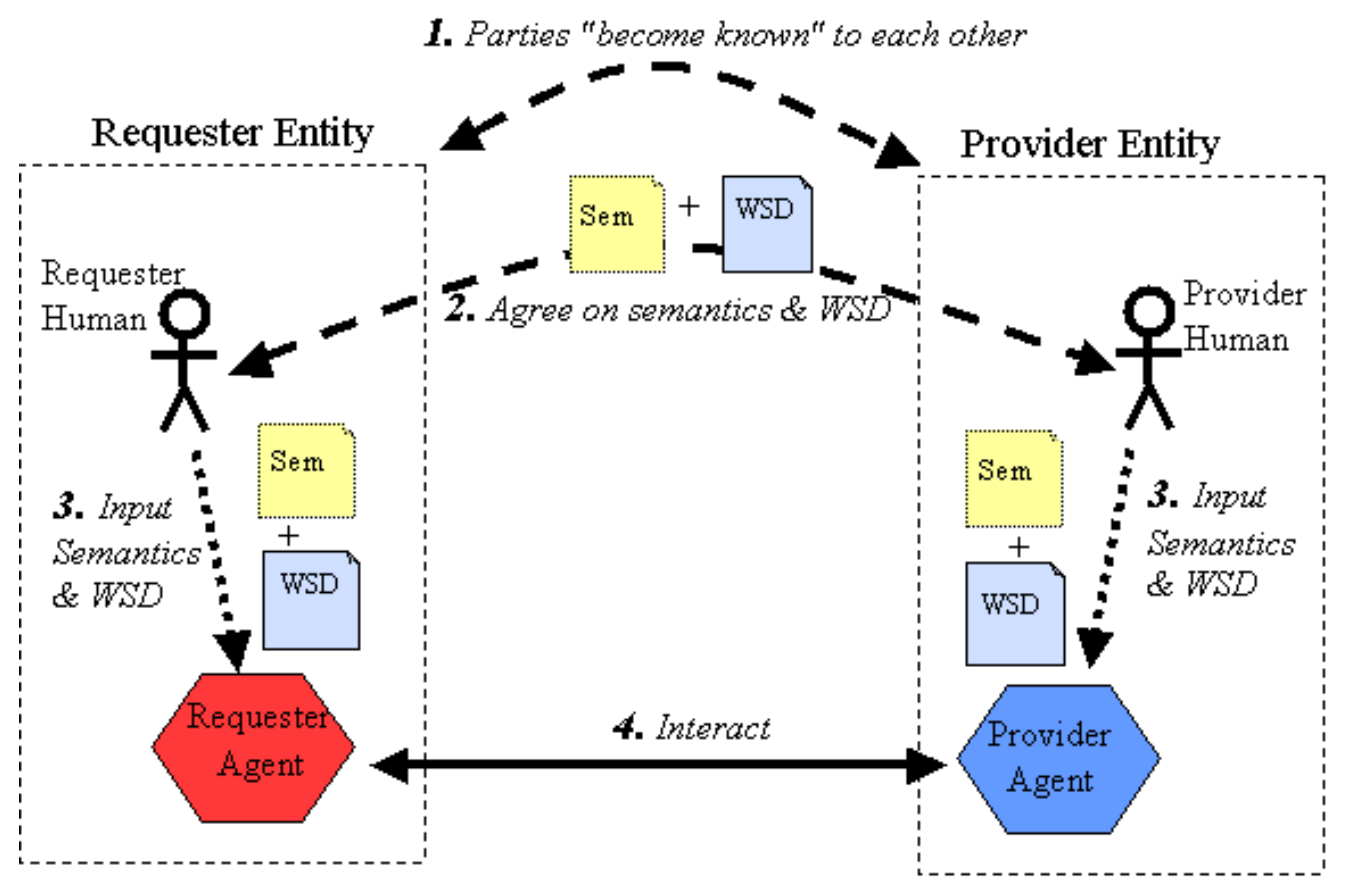

Gambar 1. Proses Pertukaran Data Pada Web Service

\subsection{Sistem Tutorial}

Menurut Sanjaya, sebuah system adalah suatu kesatuan komponen yang saling berkesinambungan untuk mencapai satu tujuan tertentu [8]. Sistem tutorial adalah program bantuan dalam proses belajar mandiri yang bertujuan memicu proses belajar peserta apabila dalam belajar individu ataupun kelompok mengalami kesulitan. Pada tutorial biasanya juga dilengkapi informasi tentang objeknya dan petunjuk untuk suatu operasi tertentu. Beberapa ciri sistem tutorial yang baik adalah menyampaikan pendahuluan dan pokok materi, menyediakan respon dan deteksi jawaban, serta menampilkan hasil pembelajaran. Pendahuluan berisi pembukaan, identitas mata kuliah, programer, judul, pokok materi, dan petunjuk atau langkah pembelajaran yang akan ditempuh. Pokok materi dapat dibagi dalam dua bagian, yaitu bagian uraian materi dan bagian evaluasi. Faktor pendukung yang berbentuk soal bisa dikonstruksi dalam bentuk pilihan ganda. Hal ini dilakukan guna memudahkan desain link keterhubungan antar deteksi jawaban benar dan salah. Sistem tutorial juga memerlukan kemampuan untuk menyediakan respon terhadap jawaban yang diberikan pengguna. Lebih lanjut, untuk memberikan gambaran hasil akhir dari sejumlah pertanyaan yang disajikan, maka skor akan memperlihatkan berapa kali pengguna menjawab salah, berapa kali menjawab benar dan skor akumulatif jawaban benar. Untuk ini, hasil pembelajaran dapat disajikan dalam bentuk skor angka atau visualisasi menggunakan berbagai macam jenis grafik.

\section{Metode Penelitian}

Pemilihan metode penelitian yang tepat sangatlah penting untuk memecah siklus pengembangan perangkat lunak sehingga memudahkan untuk mengevaluasi setiap bagian. Metode uang digunakan untuk penelitian ini diadaptasi dari metode waterfall seperti ditunjukkan pada Gambar 2. Pada 
penelitian ini metode penelitian mencakup tahap observasi, studi pustaka, analisis sistem, perancangan sistem, implementasi sistem, integrasi dan pengujian sistem, serta pemeliharaan [9].

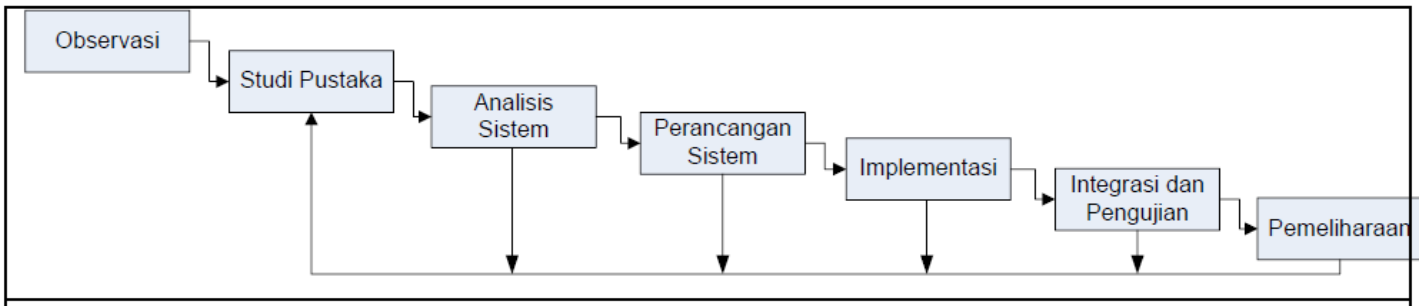

Gambar 2. Metode Penelitian

Observasi merupakan tahap pengumpulan data dengan mengadakan pengamatan dan pencatatan dengan cara meninjau langsung tempat penelitian. Studi pustaka merupakan tahap pengumpulan data yang diperoleh dari berbagai buku dan media lain sebagai referensi penulis dalam menyusun penelitian. Analisis sistem mencakup analisis kebutuhan dari sistem yang dapat berupa aturan-aturan serta metode proses yang akan diterapkan. Perancangan sistem meliputi perancangan database, interface dan programming. Implementasi sistem merupakan tahap pembangunan perangkat lunak, dalam penelitian ini menggunakan bahasa pemrograman berbasis AJaX, dengan database MySQL 5, dan metode $W e b$ Service. Tahap terakhir adalah pemeliharan, dimana programmer melakukan pelatihan, perbaikan dan penambahan sesuai kebutuhan pengguna

\section{Analisis Dan Perancangan Sistem}

Sistem yang dibangun dalam penelitian ini adalah sebuah sistem tutorial yang menyajikan meteri berupa script pemrograman dengan kemampuan untuk mengeksekusi script tersebut. Perancangan sistem mencakup rancangan arsitektur sistem, rancangan database, dan alir data

\subsection{Rancangan Arsitektur Sistem}

Rancangan arsitektur sistem pada Gambar 3 menunjukkan bahwa sistem tutorial yang dibangun memiliki dua database, yang digunakan untuk proses interoperabilitas pengiriman data dari satu database ke database yang lain menggunakan metode web service. Sedangkan AJaX digunakan di bagian sistem untuk aplikasi client. Penggunaan dua database dan web-server antara program aplikasi tutorial dengan quiz server bertujuan untuk menjaga independensi data quiz, yang mana quiz yang disajikan berasal dari pihak yang berkompeten. Sedangkan penggunaan web service bertujuan untuk media interoperabilitas request dan respond data antar dua database. Selain itu, untuk tujuan pengembangan, dikarenakan tidak menutup kemungkinan bahwa service yang digunakan bisa digunakan pada aplikasi yang lain yang berbeda platform. 


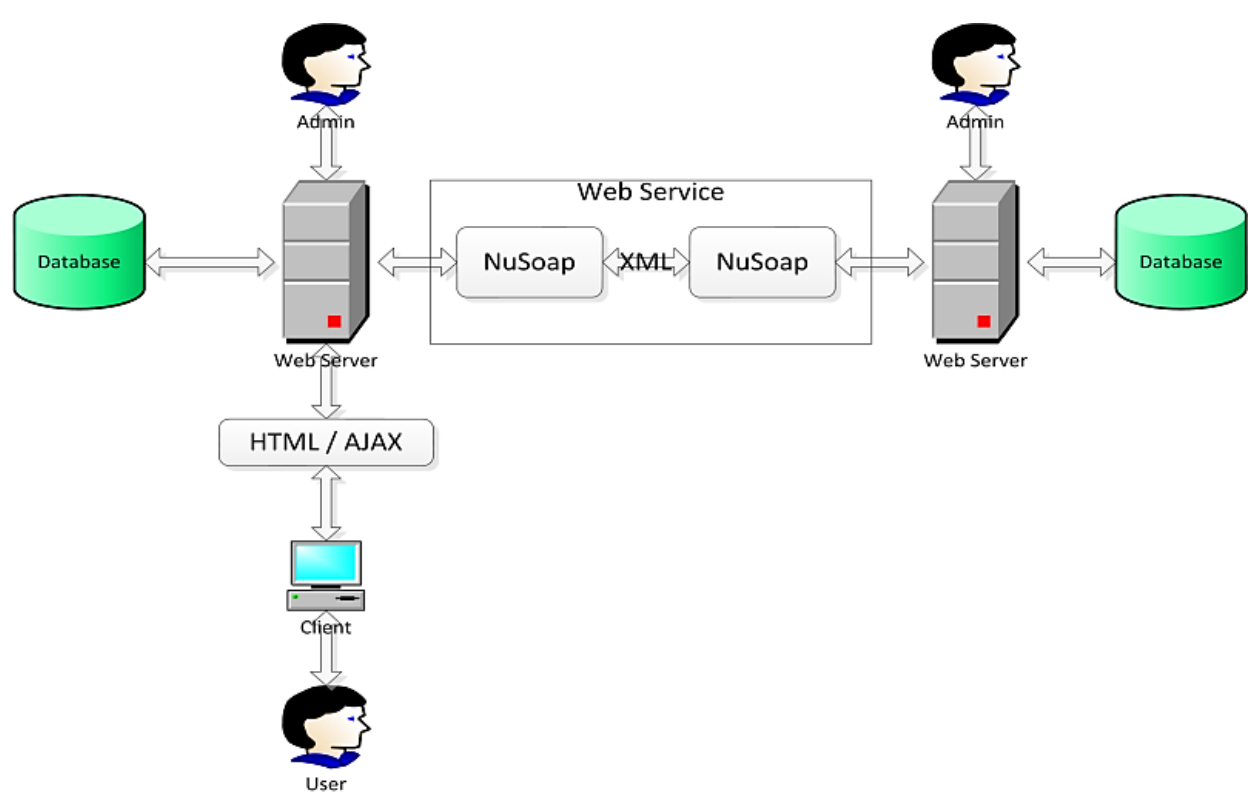

Gambar 3. Rancangan Arsitektur Sistem

\subsection{Rancangan Basis Data}

Rancangan basis data merupakan serangkaian pertanyaan spesifik yang relevan dangan berbagai pemrosesan data, misalnya objek data yang akan diproses oleh sistem, komposisi masingmasing objek data dan atribut yang menggambarkan serta bagaimana hubungannya antar masingmasing objek data tersebut. Basis data dirancang agar data yang berkaitan ini dapat terorganisir dan tersimpan dengan baik sehingga memudahkan dalam pencarian dan manipulasi data. Untuk memodelkan data yang terlibat dalam sistem, digunakan diagram hubungan entitas (Entitity Relationship Diagram) atau biasa disingkat ERD. Terdapat tiga komponen utama dalam diagram hubungan entitas yaitu objek data, atribut objek data, dan hubungan antar objek data. ERD untuk sistem tutorial pada penelitian dtunjukkan pada Gambar 4.

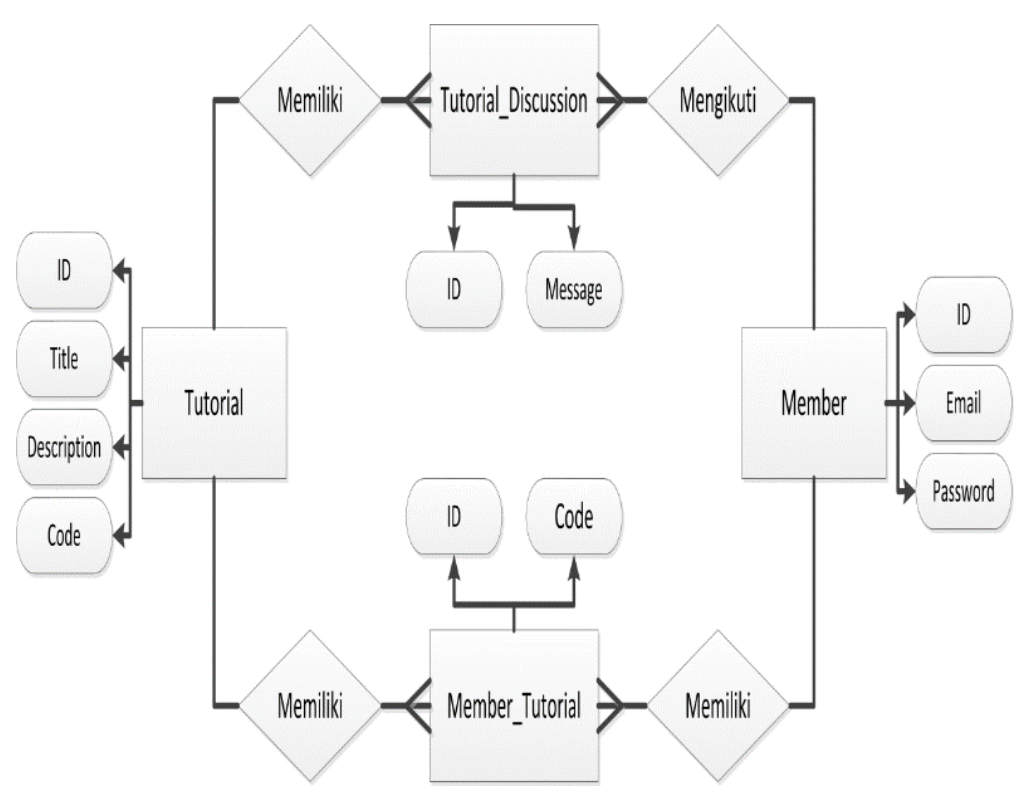

Gambar 4. Entity Relationship Diagram Untuk Sistem Tutorial 
Beberapa aturan bisnis (business rules) dalam rancangan basis data sistem aplikasi tutorial ini seperti: satu member dapat memilih beberapa jenis tutorial;

1. Satu tutorial hanya memiliki satu fasilitas untuk diskusi sesuai dengan topik tutorial yang dipilih;

2. Satu tutorial memiliki fasilitas untuk menyimpan beberapa contoh script sesuai dengan topic tutorial yang dipilih;

3. Satu member memmiliki fasilitas untuk mendownload beberapa data yang tersedia dalam daftar menu download;

4. Satu member dapat mengikuti beberapa quiz.

\subsection{Rancangan Alir Data}

Rancangan alir data merupakan alat yang biasa dipakai untuk mendokumentasikan keseluruhan proses didalam sistem. Secara umum rancangan alir data ditunjukkan dalam Gambar 5.

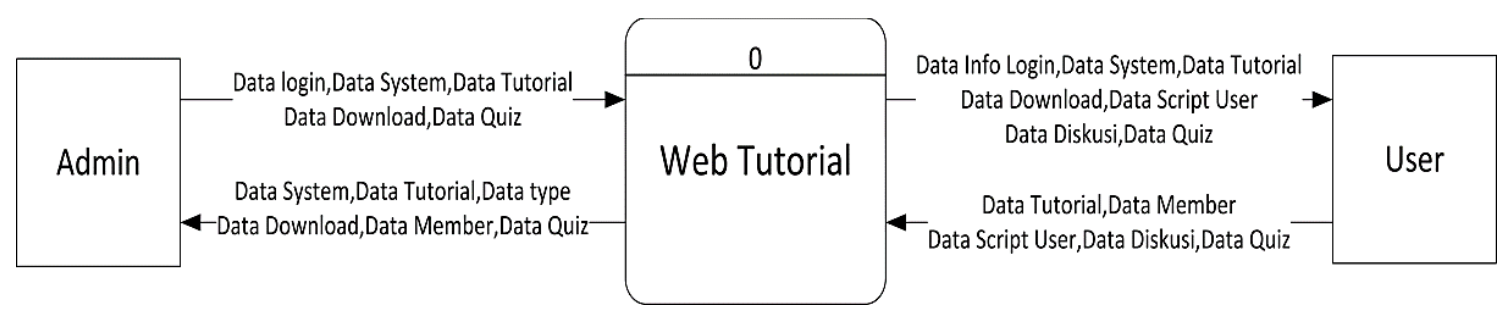

Gambar 5. Rancangan Alir Data

Pengguna yang terlibat dalam sistem ini adalah user sebagai pengguna umum maupun member dan admin sebagai pengelola data. Admin memberi masukan berupa data system, data tutorial, data download, data quiz. Sedangkan user dapat memberi masukan berupa data tutorial, data script user, data diskusi dan data quiz. Selain itu, user dapat menerima output dari sistem berupa data tutorial, data script user, data diskusi, data download dan data quiz.

\section{Hasil Dan Pembahasan}

Halaman sistem tutorial merupakan halaman yang akan digunakan oleh pengguna umum dengan beberapa content inti yang disajikan yaitu tutorial, download dan quiz. Contoh hasil pembangunan sistem ditunjukkan pada Gambar 6 dan Gambar 7.

Halaman tutorial menyajikan judul, deskripsi dan contoh kode. Contoh kode memiliki dua kriteria yaitu runnable dan unrunable, seorang pengguna dapat langsung mengetahui hasil atau bentuk visual dari contoh kode yang disajikan apabila menjumpai contoh kode yang kriterianya runnable. Sistem akan melakukan proses kompilasi dari contoh kode yang disajikan apabila pengguna menekan tombol run script pada aplikasi dan hasil dari kompilasi contoh kode disajikan menggunakan pop-up browser. Halaman quiz menyajikan pertanyaan dan pilihan jawaban disajikan menggunakan metode web service Metode web service diterapkan dibagian quiz karena data yang diambil untuk berasal dari database yang berbeda dari aplikasi yang dijalankan. Pemilihan metode webservice mendukung proses interoperability antar aplikasi, dengan demikian penyajian data dapat diatur tanpa terpengaruh oleh perbedaan platform. 


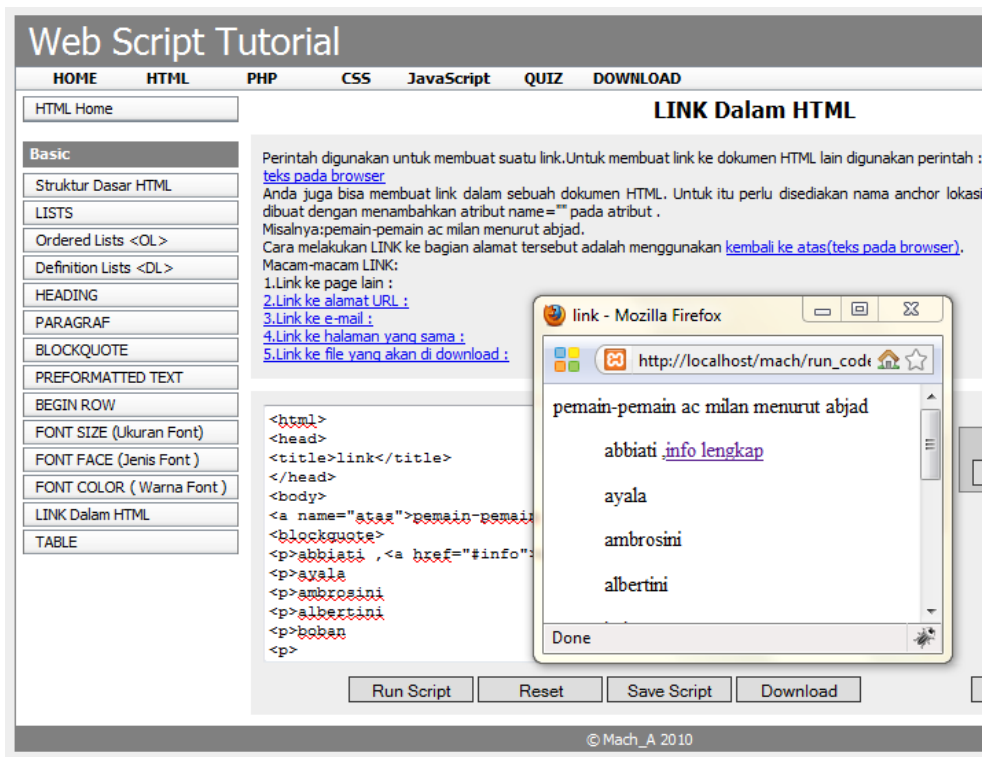

Gambar 6. Halaman Tutorial

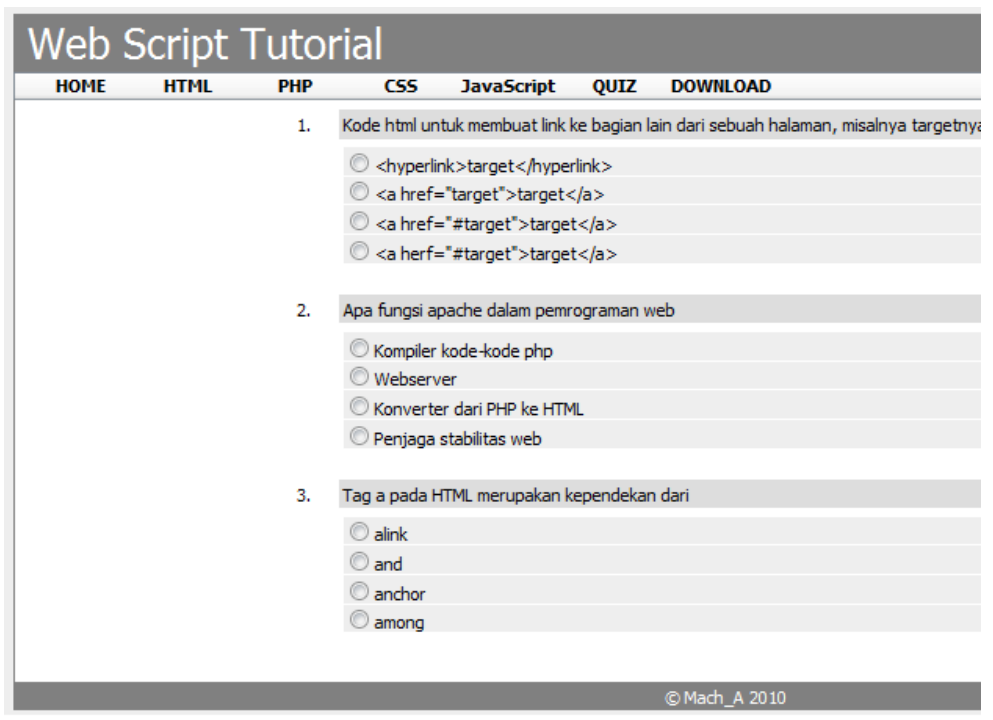

Gambar 7. Halaman Quiz

Beberapa keunggulan penerapan Teknologi AJaX pada system tutorial ini seperti: pemrosesan dilakukan diserver, hal ini berdampak pada sisi client, jika client tidak disibukkan dengan ada pemrosesan maka bisa disimpulkan bahwa data yang akan disajikan pada aplikasi client bisa lebih menghemat waktu dan bandwith. Jika kita lihat di $A J a X$, data yang dikirimkan dari server biasanya berupa data $X M L$, maka di $A H a H$ itu sudah tidak dilakukan karena $A H a H$ memiliki method yang berbeda yaitu menanamkan langsung $H T M L$ dalam halaman $D O M$, hal ini yang membuat berkurangnya kebutuhan untuk parasing sehingga waktu penyajian dapat lebih cepat. Program yang dibuat dapat lebih rapi dan terstuktur, sehingga membuat ukuran file lebih kecil. Dapat disimpulkan jika ukuran file kecil maka waktu downloadnya dapat lebih cepat. Kita bisa melihat pada Gambar 7 untuk mengakses halaman sistem bisa dilakukan secara bersaman pada saat awal, pengambilan data dengan metode XmlHttpRequest terbukti dapat menambah performa sistem lebih baik. 


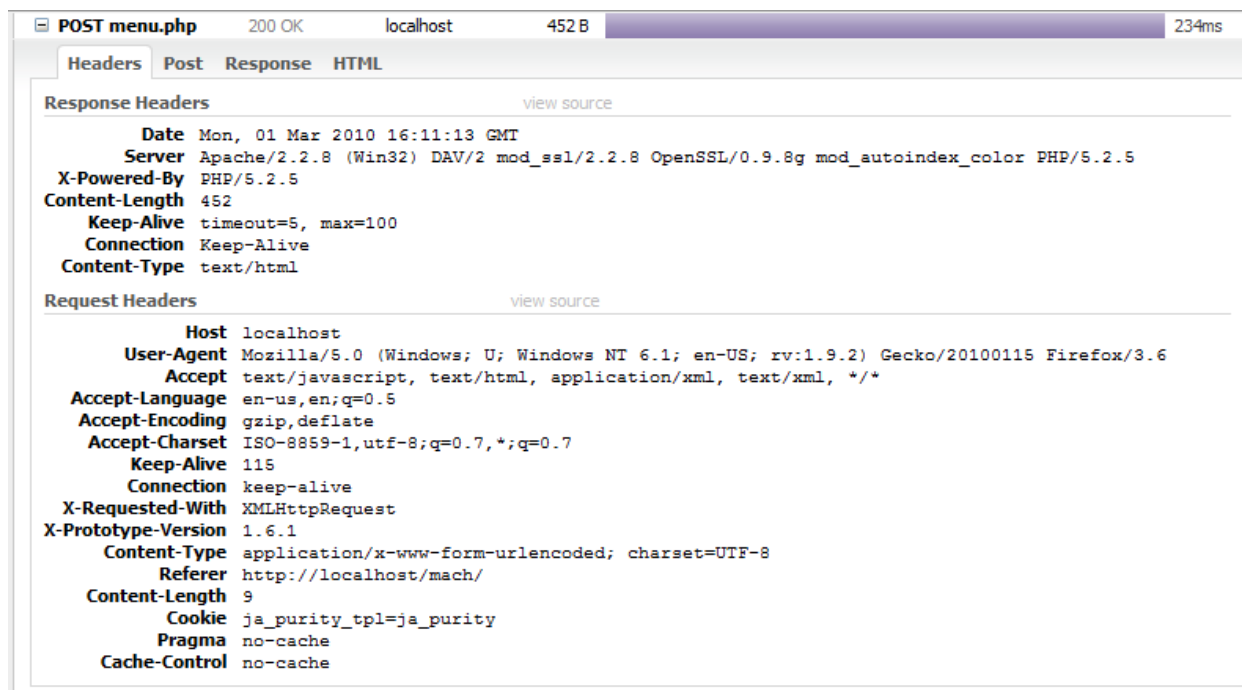

\section{Gambar 8. Metode Transfer Data Menggunakan AJax}

Sedangkan penerapan web service dititik beratkan pada koneksi pengiriman data dari server quiz keaplikasi client. Protokol server yang digunakan adalah NuSOAP. Beberapa keunggulan penerapan ini termasuk: tidak tergantung pada platform dan bagaimana web service diimplementasikan, interoperabilitas antar aplikasi yang diterapkan sangat baik, hal ini dibuktikan dengan keakuratan merespon request dari client dan kestabilan mengirimkan kembali hasil dari request, hasil dari pengiriman request data dapat ditampilkan sesuka programmer dan bisa disajikan menggunakan CSS untuk desain antar muka.

\section{Kesimpulan}

Berdasarkan hasil penelitian ini dapat diambil beberapa kesimpulan sebagai berikut :

1. Sistem yang berhasil dibangun adalah sistem tutorial pemrograman web dengan dukungan AJaX dan web service sebagai media pembelajaran dan dengan adanya aplikasi tutorial ini dapat memberikan sebuah alternatif lain dalam penyampaian informasi secara cepat, aktual, komunikatif dan praktis.

2. Penggunaan model pembelajaran tutorial pemrograman web dinamis dapat meningkatkan penguasaan konsep dan memperbaiki sikap belajar. Selain itu juga dapat membantu dalam memahami materi (konsep) yang diajarkan, dengan cara konsep-konsep yang bersifat abstrak oleh model tutorial pemrograman web divisualisasikan menjadi lebih konkrit. Sehingga tujuan pembelajaran dan proses pembelajarannya menjadi lebih bermakna. Dengan pembelajaran bermakana, maka pengguna akan mencapai hasil belajar yang maksimal atau lebih baik dari sebelumnya.

3. Pengambilan dan menampilkan data lebih cepat dapat terjadi karena ukuran data yang kecil dan pembuatan tampilan dilakukan pada komputer klien. Ukuran data yang lebih kecil berdampak pada traffic data yang lebih kecil pada jaringan dan pemrosesan yang dilakukan pada sisi klien membuat server dapat bekerja dengan lebih leluasa dan dapat merespon request yang lebih banyak.

4. Dengan metode web service dapat menambah variasi dalam interoperabilitas antar aplikasi, terbukti ketika sistem diimplementasikan, koneksi dari web client keserver quiz memiliki 
performa yang lebih baik dibanding querry biasa, dan data yang disajikan melalui metode web service dapat disajikan semau atau sesuka kita dengan artian data yang akan disajikan dapat diatur penempatanya untuk ditampilkan dihalaman client.

Selain itu, berdasarkan pembahasan dan kesimpulan yang telah diuraikan diatas maka dapat disarankan pada proses integrasi dapat dikembangkan lebih luas dengan membangun web service yang lebih luas.

\section{DAFTAR REFERENSI}

[1] M. I. Perkasa and E. B. Setiawan, "Pembangunan Web Service Data Masyarakat Menggunakan REST API dengan Access Token," ULTIMA Comput., vol. 10, no. 1, pp. 19-26, (2018).

[2] H. Ashaury and M. K. Sabariah, "Situs Pariwisata dengan Social Network Service dan Web Mapping Untuk Meningkatkan Pemasaran Tempat Wisata," in SNIA 2017 Seminar Nasional Informatika dan Aplikasinya, (2018), vol. 3, p. D-57.

[3] V. F. Sahara, A. Fariza, and J. A. N. Hasim, "Spatial Data Service Bencana Indonesia Berbasis Restfull Pada Platform Sahana," SEMNASKIT 2015, (2018).

[4] S. Subandi, "Rancang Bamgun Aplikasi Kepuasan Layanan Akademik Berbasis Mobile Studi Kasus: Universitas Budi Luhur," Budi Luhur Inf. Technol., vol. 15, no. 1, pp. 1-12, (2018).

[5] M. Soliman, T. Abiodun, T. Hamouda, J. Zhou, and C.-H. Lung, "Smart home: Integrating internet of things with web services and cloud computing," in 2013 IEEE 5th international conference on cloud computing technology and science, (2013), vol. 2, pp. 317-320.

[6] R. Peredo, A. Canales, A. Menchaca, and I. Peredo, "Intelligent Web-based education system for adaptive learning," Expert Syst. Appl., vol. 38, no. 12, pp. 14690-14702, (2011).

[7] D. Mabbutt, A. Freeman, and M. MacDonald, "Ajax and Web Services," in Pro ASP. NET 4.5 in VB, Springer, (2013), pp. 1111-1138.

[8] W. Sanjaya, Perencanaan dan desain sistem pembelajaran. Kencana, (2015).

[9] J. Dick, E. Hull, and K. Jackson, Requirements engineering. Springer, (2017). 